\title{
Assessment of Mycoplasma gallisepticum vaccine efficacy in a co-infection challenge model with QX-like infectious bronchitis virus
}

Dauda G. Bwala ${ }^{1,2 *}$, Solomon Ponman ${ }^{1,2}$, Neil Duncan ${ }^{3}$, Daniel B.R. Wandrag ${ }^{1}$, Celia Abolnik $^{1}$

${ }^{1}$ Poultry Section, Department of Production Animal Studies, Faculty of Veterinary Science, University of Pretoria, Private Bag X04, Onderstepoort, 0110, South Africa

${ }^{2}$ National Veterinary Research Institute, Vom-Jos, Private Mail Bag 001, Vom - Plateau State, 930010, Nigeria.

${ }^{3}$ Pathology Section, Department of Paraclinical Science, Faculty of Veterinary Science, University of Pretoria, Private Bag X04, Onderstepoort, 0110, South Africa

*Corresponding author: D.G Bwala: dgbwala@yahoo.com 


\section{ABSTRACT}

Mycoplasma gallisepticum (MG) is the primary cause of chronic respiratory disease in poultry. We investigated the protective efficacy of the live attenuated ts-11 and 6/85 MG vaccines against a local MG strain, and in order to enhance symptoms and mimic a typical field situation, we co-infected birds with a virulent strain of QX-like infectious bronchitis virus (IBV). Both vaccines showed similar ability to protect infected chickens from clinical signs, although ts-11 performed slightly better. Despite the lower protection against clinical disease, 6/85-vaccinated birds had significantly $(\mathrm{P} \leq 0.05)$ lower tracheal lesion scores and mucosal thickness at day 28 post vaccination (7 days post challenge [dpc] with MG, 2 dpc IBV) and day 31 post vaccination (10 dpc MG challenge, $5 \mathrm{dpc}$ IBV) compared to ts-11 vaccinated birds, but these difference was not significant at day 33 (12 dpc MG, 7dpc IBV). Pathogen infection and replication was assessed by qPCR, and the 6/85 vaccine produced a more significant $(\mathrm{P} \leq 0.05)$ reduction in $\mathrm{MG}$ replication in the lungs, kidneys and livers but enhanced late replication in bursae and caecal tonsils. In contrast, the ts- 11 vaccine had a more pronounced reductive effect on replication in tracheas, air sacs, bursae and heart at days 28 and 31, yet increased replication in lungs. Interestingly, both vaccines provided nonspecific protection against IBV challenge. The co-challenge model provided useful data on vaccine efficacy, especially on day 31 and 33, and tracheas, lungs, air sacs, kidneys, liver and caecal tonsils were the best organs to assess.

KEYWORDS: Mycoplasma gallisepticum, QX-like Infectious bronchitis virus, qPCR, vaccines, challenge, co-infection model 


\section{RESEARCH HIGHLIGHTS}

- Vaccinated chickens were challenged with virulent field MG and QX-like IBV strains

- Ts-11 and 6/85 vaccines protected against a unique South African MG field strain

- Vaccines differed in their ability to prevent MG replication in various tissues

- Non-specific protection by the vaccines against IBV infection was observed

\section{INTRODUCTION}

Mycoplasma gallisepticum (MG) is listed by the World Animal Health Organization (OIE) as one of the most pathogenic avian mycoplasmas and the primary cause of chronic respiratory disease (CRD) in poultry (OIE, 2008). MG infection usually produces mild disease, but mycoplasmas' ability to synergize with other poultry respiratory pathogens such as infectious bronchitis virus (IBV), Newcastle disease virus (NDV) and Escherichia coli (E. coli) to exacerbate infections under intensive poultry management conditions makes avian mycoplasmosis a disease of economic significance (Rodriguez \& Kleven, 1980; Nakamura et al., 1994). Generally, poultry farmers have depended on vaccination in combination with antimicrobials and biosecurity to control mycoplasmosis (Armour et al., 2013). Among the live vaccines available for MG control, strains ts-11 (Whithear 1996) and 6/85 (Evans \& Hafez, 1992) have long been applied in South Africa, whereas the F strain vaccine (Adler et al., 1960; Luginbuhl et al., 1967) was not registered for use until the first quarter of 2015. MG vaccine strains ts-11 and 6/85 are both attenuated and avirulent and have been reported to be safe and efficacious (Evans \& Hafez, 1992; Whithear, 1996). The use of live-attenuated MG vaccines in some parts of the world has, however, been reported to have variable efficacy in challenge experiments (Abd-El-Motelib \& Kleven, 1993), and in South Africa, field reports have suggested suboptimal protection of flocks against infection with local MG isolates, which were reported to be genetically unique (Armour et al., 2013). 
We assessed the protective efficacy of ts-11 and 6/85 MG vaccines against challenge with a virulent South African MG field strain. Since the infection of Specific Pathogen Free (SPF) White Leghorn chickens even with virulent MG field strains often produces limited clinical signs in the highly controlled environment of isolation cabinets (our unpublished laboratory data), we co-infected the chickens with a virulent QX-like strain of IBV. This is comparable to a field situation where flocks are frequently challenged by multiple microorganisms. The use of a co-infection model allowed us to assess the protective effects of the vaccines, based on more pronounced clinical signs, macro and micropathological lesions, and quantitative tissue distribution of the pathogens following challenge.

\section{MATERIALS AND METHODS}

Experimental animals and housing. Approval for the animal procedures was obtained from University of Pretoria's Animal Ethics Committee. The study was conducted at the Faculty of Veterinary Science's Poultry Biosafety Level 3 facility. Three-week-old SPF White Leghorn cockerels were supplied by Avifarms (Pty) Ltd, Pretoria, and birds were randomly assigned into groups of 12 in negative pressure isolators fitted with HEPA-filtered inlet and outlet air. The isolators were set at a temperature of $27^{\circ} \mathrm{C}$ and natural light was provided. Water and feed was supplied ad-libitum for the duration of the study. The birds were reared in the isolation units for two weeks to enable them to acclimatise and reach 5 weeks of age, after which birds are usually vaccinated against mycoplasmosis (Noormohammadi et al., 2002).

Vaccination. The ts-11 vaccine supplied by Tradevet, Johannesburg, is a frozen live culture of MG (Merial ${ }^{\circledR}$ Select, Inc. Gainesville, GA 30503, USA). It is formulated as $30 \mathrm{ml}$ vaccine containing 1000 doses with a titre of $10^{8.6}$ Colony Forming Units (CFUs) per dose and was stored at $-80^{\circ} \mathrm{C}$ until use. The vaccine was thawed, shaken well to mix and birds were 
vaccinated with 1 drop per eye. The Nobilis ${ }^{\circledR}$ M. gallisepticum 6/85 vaccine was sourced from MSD Animal Health South Africa (Isando). The 6/85 vaccine is also a live, attenuated, freeze-dried vaccine containing $10^{7.0} \mathrm{CFUs}$ per dose. Although recommended for spray application, the vaccine (1000 dose vials) was resuspended in $30 \mathrm{ml}$ sterile Oculo $\mathrm{Nasal}^{\circledR}$ diluent (a water-based solvent containing patent blue, potassium dihydrogen phosphate and disodium chloride produced specifically for oculo/nasal application of live poultry vaccines) (MSD Animal Health South Africa, Isando), and birds were vaccinated according to the manufacturers' recommended doses with a drop per eye for a head-to-head comparison with ts-11.

Pathogen challenge strains. MG field strain B2159/13 was isolated in October 2013 from a flock showing typical signs of mycoplasmosis. The strain was confirmed by Illumina ultradeep sequencing to be a pure culture, and is typical one of the unique South African "wild types" described by Armour et al. (2013) (Bwala, 2017). B2159/13 was cultured to a titre of $3.125 \times 10^{9} \mathrm{CFU} / \mathrm{ml}$ and stored at $-80^{\circ} \mathrm{C}$ until use. Just prior to challenge, the B2159/13 stock was thawed and diluted with sterile Oculo Nasal ${ }^{\circledR}$ diluent to $1.56 \times 10^{8}$ CFUs per dose. Birds were then challenged with 1 drop $(50 \mu l)$ into each eye.

IBV QX-like strain 3665/11 was isolated from a broiler flock in 2011 (Knoetze et al., 2014). The virus was propagated and titrated in SPF eggs to a titre of $10^{7.2} \mathrm{EID}_{50} / \mathrm{ml}$, and the purity of the viral stock was confirmed by Illumina ${ }^{\circledR}$ ultra-deep sequencing (Abolnik, 2015). Prior to challenge, virus in allantoic fluid was diluted in sterile Oculo Nasal ${ }^{\circledR}$ diluent to a challenge dose of $10^{4} \mathrm{EID}_{50}$ per $100 \mu 1$, i.e. one drop per eye. The challenge dose and optimal day for ciliary motility scoring had been experimentally determined in a previous clinical trial (unpublished data). 
Experimental design. Eight treatment groups of 12 birds per group were housed in 8 isolation units. Due to a restricted number of isolators, the unvaccinated, unchallenged, negative control group (group 9) was housed in a separate facility. At day 0 of the trial (5 weeks of age), birds were vaccinated with ts-11 and 6/85 vaccine, while the remaining 10 birds per group were then challenged with MG strain B2159/13 and QX-like IBV strain 3665/11. (Table 1) Birds were observed twice daily and clinical signs were scored according to a modified Naylor et al. (1992) scoring method as follows: 0 = no signs; 1 = ruffled feathers \& huddling or sickly appearance; $2=$ clear nasal exudate/discharge; $3=$ turbid nasal exudate/discharge; $4=$ as for 3 , and/or with swollen infra-orbital sinuses and/or conjunctivitis. Planned euthanasia post-vaccination (day 21) and post-challenge (days 28, 31 and 33) were carried out on randomly selected birds to assess tissue pathologies caused by the vaccines and the challenge pathogens respectively. Birds were bled from the brachial wing vein pre-vaccination and then weekly after vaccination on days 7, 14, 21 and 28, and MG-specific antibodies were evaluated using a commercial MG-specific ELISA and xChek $^{\circledR} 3.3$ software (IDEXX Laboratories, Inc., Westbrook, ME).

Post mortem, macroscopic examination and tissue sampling. Gross lesions were recorded at necropsy. Trachea, liver, heart, spleen, caecal tonsils, bursa of Fabricius, air sacs, lung and kidneys (in the order of removal) were sampled aseptically into individual sterile containers and stored at $-80^{\circ} \mathrm{C}$ until used for quantitative PCR. Duplicate samples for histopathology were preserved in $10 \%$ buffered formalin.

Ciliary activity of tracheal explants. Tracheas harvested on day 33 were immediately immersed in phosphate-buffered saline (PBS) supplemented with $1 \%$ glucose. Ten $1-2 \mathrm{~mm}$ tracheal ring sections were prepared from each trachea ( 3 from the proximal, 4 from the mid, 
Table 1: Overview of the experimental design

\begin{tabular}{|c|c|c|c|c|c|c|c|}
\hline \multirow{3}{*}{ 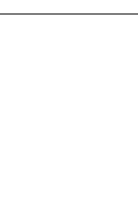 } & \multirow{3}{*}{ Day 0} & \multicolumn{2}{|c|}{ Day 21} & \multirow{3}{*}{$\begin{array}{c}\text { Day } 26 \\
5 \text { dpc with } M G\end{array}$} & \multirow{3}{*}{$\begin{array}{c}\text { Day } 28 \\
7 d p c \text { with } M G ; \\
2 d p c \text { with } I B V\end{array}$} & \multirow{3}{*}{$\begin{array}{c}\text { Day } 31 \\
10 d p c \text { with } M G \\
5 \text { dpc with } I B V\end{array}$} & \multirow{3}{*}{$\begin{array}{c}\text { Day } 33 \\
12 d p c \text { with } M G \\
7 d p c \text { with } I B V\end{array}$} \\
\hline & & 21 days post $\Lambda$ & G vaccination & & & & \\
\hline & & & & & & & \\
\hline Group $^{a}$ & MG Vaccine & Euthanized & MG challenge & IBV QX challenge & Euthanized & Euthanized & Euthanized \\
\hline & (12/group) & pre-challenge & $(\mathrm{n}=10 /$ group $)$ & ( $\mathrm{n}=10 /$ group $)$ & & & \\
\hline 1 & yes, ts- $11^{b}$ & $\mathrm{n}=2$ & no & yes & $\mathrm{n}=2$ & $\mathrm{n}=2$ & $\mathrm{n}=6$ \\
\hline 2 & yes, ts- $11^{b}$ & $\mathrm{n}=2$ & yes & yes & $\mathrm{n}=2$ & $\mathrm{n}=2$ & $\mathrm{n}=6$ \\
\hline 3 & yes, ts- $11^{b}$ & $\mathrm{n}=2$ & no & no & $\mathrm{n}=2$ & $\mathrm{n}=2$ & $n=6$ \\
\hline 4 & no & no & yes & yes & $\mathrm{n}=2$ & $\mathrm{n}=2$ & $\mathrm{n}=6$ \\
\hline 5 & yes, $6 / 85^{b}$ & $\mathrm{n}=2$ & no & yes & $\mathrm{n}=2$ & $\mathrm{n}=2$ & $\mathrm{n}=6$ \\
\hline 6 & yes, $6 / 85^{b}$ & $\mathrm{n}=2$ & yes & yes & $\mathrm{n}=2$ & $\mathrm{n}=2$ & $\mathrm{n}=6$ \\
\hline 7 & no & no & no & yes & $\mathrm{n}=2$ & $\mathrm{n}=2$ & $n=6$ \\
\hline 8 & no & no & yes & no & $\mathrm{n}=2$ & $\mathrm{n}=2$ & $\mathrm{n}=6$ \\
\hline 9 & no $^{b}$ & $\mathrm{n}=2$ & no & no & $\mathrm{n}=2$ & $\mathrm{n}=2$ & $n=6$ \\
\hline
\end{tabular}

dpc - days post challenge; MG - Mycoplasma gallisepticum; IBV - infectious bronchitis virus

a5-week old SPF white leghorn chickens per isolator placed 14 days prior to Day 0 ( $n=12$ /group)

bsera was drawn pre-vaccination on Day 0 and then weekly on days 7, 14, 21 and 28 from all birds in each group 
and 3 from the distal section) and examined by low power microscopy (x10). The ciliary activity of each tracheal ring was scored as a percentage ranging from 100\% (normal ciliary distribution and activity) to $0 \%$ (complete ciliostasis or ciliary depletion). The ciliary activity scores for the 10 rings of each trachea were then graded on a scale of 0 (scores of $0 \%<50 \%$ ) or 1 (scores of $50 \% \leq 100 \%$ ), and the mean graded scores were then calculated for each group. A group percentage score of $\geq 50 \%$ was considered as unaffected.

Histopathology. Formalin-preserved tissues were routinely processed and stained with haematoxylin and eosin $(\mathrm{H} \& \mathrm{E})$ as per the method described by Bancroft \& Gamble (2008). Cross-sections of each trachea were microscopically examined and mucosal lesions scored as described by Nunoya et al., (1987). Tracheal mucosa thickness measurements (in micrometres) were made at four equidistant points around the tracheal ring circumference (Hudson et al., 2006). Histopathological lesions of lung and trachea were also assessed, while bursal lesion scoring was conducted as described by Muskett et al. (1979).

Pathogen quantitation by real-time PCR. Tissues from each group were pooled by combining $20 \mu \mathrm{g}$ of each into a MagNA Lyser® Green Beads tube (Roche, Germany) containing 1ml of MagNA PuRE 96 External Lysis Buffer (Roche Diagnostic GmbH, Germany), followed by homogenization with a MagNA Lyser® Instrument (Roche Diagnostics, Germany). Nucleic acids were extracted using an automated MagNA Pure LC Instrument (Roche Diagnostics, Germany).

IBV RNA genomes were detected and quantified by a TaqMan ${ }^{\circledR}$ reverse-transcriptase PCR (RT-PCR) assay using VetMax ${ }^{\text {TM}}$-Plus One-Step RT-PCR kit (Applied Biosystems, California). The primers and probe were designed to amplify a region of the S1 gene of QX- 
like IBV strain 3665/11: IBV S925FOR: CCAAACACAAACAGCTCAGAGTGG; IBV S1144REV: TACCACTAAARACAGATTGCTTRC; and IBV-QXPRO: CAGTTtGTGTAtAAGGCAAGC (MGB-FAM). Nine $\mu \mathrm{l}$ qRT-PCR reaction mixtures contained $1.35 \mu 1$ of PCR-grade water, $6 \mu 1$ of 2x RT-PCR buffer, $0.5 \mu 1$ RT enzyme mix, 0.5 $\mu \mathrm{l}$ of $12.5 \mathrm{pmol} / \mu \mathrm{l}$ of forward and reverse primer, and $0.15 \mu \mathrm{l}$ of $5 \mathrm{pmol} / \mu 1$ probe was used and quantitative RT-PCR reactions were performed under the following conditions: one cycle of reverse transcription at $48^{\circ} \mathrm{C}$ for 10 minutes, one cycle of $\mathrm{RT}$ inactivation/initial denaturation at $95^{\circ} \mathrm{C}$ for 10 minutes followed by 40 cycles of $95^{\circ} \mathrm{C}$ for 15 seconds and $60^{\circ} \mathrm{C}$ for 45 seconds for amplification.

MG genomic DNA was detected and quantified by a TaqMan ${ }^{\circledR}$ PCR assay using the VetMax ${ }^{\text {TM}}$-Plus qPCR kit (Applied Biosystems, California). The primers and probes were designed to detect a region of $\mathrm{ClpB}$ protein specific to South African MG field strain B2159/13, and does not detect the ts-11 or 6/89 MG vaccine strains (validation data not shown). Sequences were as follows: MgFOR: CGGTATTAGAACCATGCTTAAC; MgREV: $\quad$ CAACCWGGTGTTTATCAGACGC; GAGCTATAGCGAAAAGGTCTTTATCA (MGB-VIC). The $12 \mu 1$ qPCR reaction mixtures each contained $6 \mu 1$ of PCR-grade water, $5 \mu 1$ of 2x VetMax qPCR Master mix, $0.5 \mu 1$ of 10 $\mathrm{pmol} / \mu \mathrm{l}$ forward and reverse primer, and $0.15 \mu \mathrm{l}$ of $5 \mathrm{pmol} / \mu \mathrm{l}$ probe. Reactions were performed under the following cycling conditions: one cycle of enzyme activation/template denaturation at $95^{\circ} \mathrm{C}$ for 10 minutes followed by amplification of 40 cycles at $95^{\circ} \mathrm{C}$ for 15 seconds and $60^{\circ} \mathrm{C}$ for 45 seconds. Three microliters of the nucleic acid extracts or no template control (NTC) were used for each RT-PCR or qPCR reaction, and all samples were tested in duplicate, on an Applied Biosystems StepOne Plus real-time PCR system (Life Technologies Ltd., Carlsbad, CA). Standard curves were generated using 10-fold serial dilutions of the respective challenge pathogens' nucleic acids. 
Statistical Analysis. Clinical signs observed between groups following challenge were subjected to a test for significance using Fisher's exact test calculator with a $2 \times 2$ contingency table (http://www.socscistatistics.com/tests/fisher/Default2.aspx $)$. Values for tracheal mucosal thickness measurements, tracheal microscopic lesion scores (mucosal cellular infiltration) and qPCR were analysed by Student's t-test (chi-square) and two-way Analysis of Variance (ANOVA) (Dean et al., 2013): (http://www.openepi.com/). Differences were considered significant at $\mathrm{P} \leq 0.05$.

\section{RESULTS}

Clinical signs. No clinical signs were observed in any of the vaccinated birds in the 21-day post-vaccination monitoring period. Following MG challenge, only 1/10 (10\%) and 2/10 (20\%) of the unvaccinated birds in group 4 and group 8 respectively were observed to be depressed with ruffled feathers, but clinical signs were only evident at 5 days post MG challenge (Table 2). Birds vaccinated with ts-11 (group 2) and 6/85 (group 6) did not develop any clinical signs after challenge with MG. The clinical signs observed between groups following MG challenge were however not significant $(\mathrm{P}>0.05)$.

Subsequent IBV challenge however resulted in depression and ruffling of feathers of $20 \%$, $10 \%, 20 \%$ and $40 \%$ of birds in groups $2,5,6$, and 7 respectively. These signs were first recorded three days' post-IBV challenge in group 7. Birds in unvaccinated groups 4 (challenged with both pathogens), 7 (challenged with IBV only) and 8 (challenged with MG only) had additional clinical signs of inappetance, depression and green watery diarrhoea. Two birds each from groups 4 and 8 also displayed exaggerated head shaking. One bird from group 4 and two birds from group 8 had periocular swelling with closure of the affected eyes, but no visible discharge. Clinical signs increased in severity as the days progressed, and the number of clinically diseased chickens in group 4 were statistically significant $(\mathrm{P}<0.05)$. 
Table 2: Results for vaccinated or unvaccinated chickens challenged with MG, IBV or both pathogens

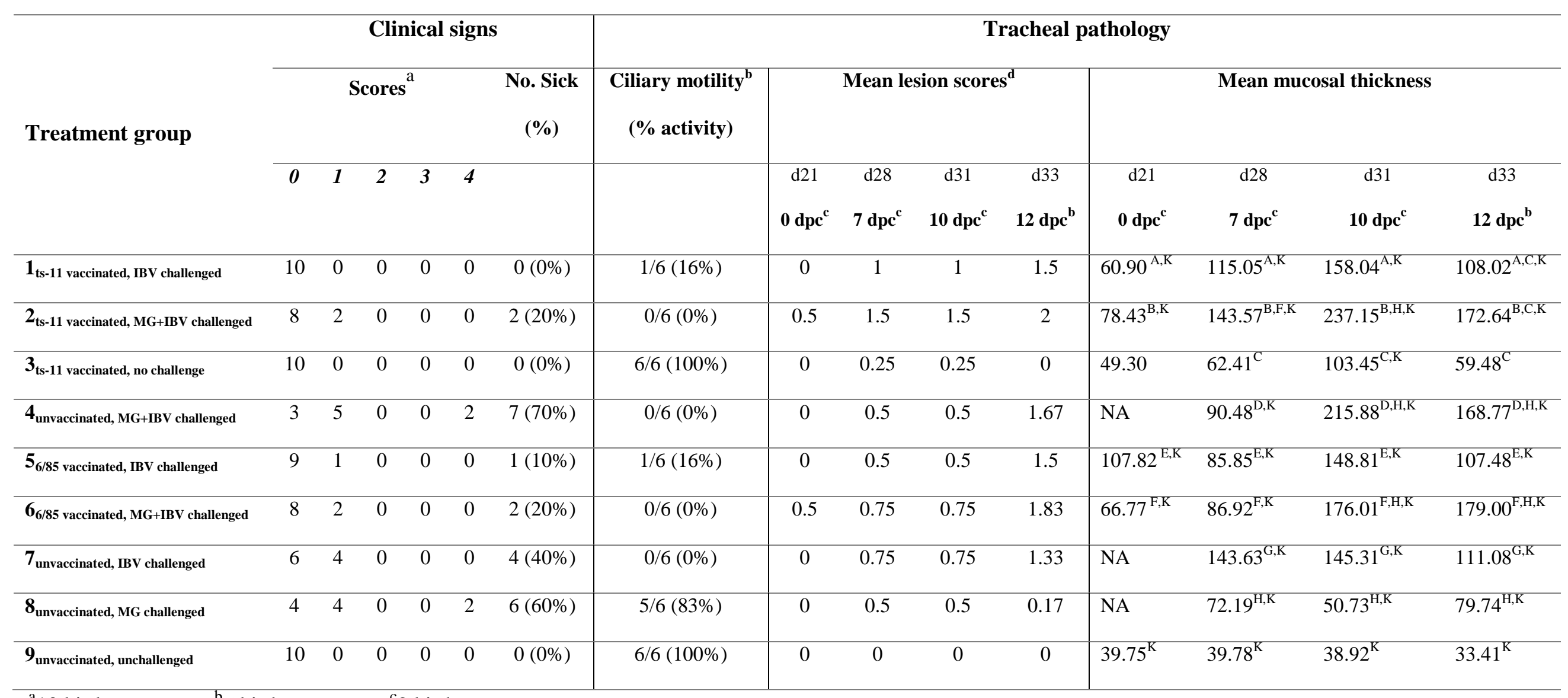

${ }^{\mathrm{a}} 10$ birds per group; ${ }^{\mathrm{b}} 6$ birds per group; ${ }^{\mathrm{c}} 2$ birds per group

${ }^{\mathrm{d}}$ Maximum score of 3

Upper case letters represent statistically significant differences $(\mathrm{P} \leq 0.05)$, tests for equality of variance within the co-challenged groups (groups 2 vs 4 vs 6 ) using Analysis of Variance (ANOVA) were all statistically non-significant $(\mathrm{P}>0.05)$

dpc: days post challenge with MG; MG - Mycoplasma gallisepticum; IBV - infectious bronchitis virus 
Clinically diseased birds started recovering towards the end of the trial. No mortalities were recorded. Both vaccines reduced clinical symptoms in dual infected birds, from $70 \%$ (group 4) to $20 \%$ (vaccinated groups 2 and 6), with mild symptoms compared to severely ill birds in unvaccinated groups (4 and 8). The reductions in the clinical signs between these three groups were however not significant $(\mathrm{P}>0.05)$. Birds in group 1 (ts-11 vaccinated) did not manifest any clinical signs after IBV challenge.

Gross post mortem lesions. On day 28 (7dpc with MG/ $2 \mathrm{dpc}$ with IBV), congestion of tissues, slight enlargement of spleens and oedematous bursae were recorded across challenged groups irrespective of vaccination status. There was generally an increase in the intensity of the lesions as the days post-challenge increased (Table 2). Slightly cloudy air sacs were also observed in one bird each in groups 4 (unvaccinated, MG+IBV challenged) and 8 (unvaccinated, MG challenged). Congestion and smaller haemorrhagic foci on the small intestines were recorded in the unvaccinated groups 4,7 and 8 on day 31 (10dpc with MG/ 5dpc with IBV), while bursae of birds of group 4 appeared atrophic at day 33, as they were relatively smaller than the bursa of the birds from the other groups. Lesions were generally more severe in the unvaccinated groups 4, 7 and 8, and 6/85-vaccinated groups (5 and 6) had slightly more lesions than the ts-11-vaccinated groups (1 and 2). Mucus-filled tracheas, mild lung congestion and bursal oedema was observed in a few birds of group 3 (ts-11-vaccinated only), but all were healthy at $12 \mathrm{dpc}$ when the experiment was terminated.

Tracheal explant ciliary motility assay. The results of the tracheal ciliary motility assay are presented in Table 2. Birds of group 3 (ts-11 vaccinated, unchallenged) and the negative control group 9 had normal tracheal ciliary activity (100\% motility). Due to space constraints, we were unable to include a group vaccinated with 6/85 but left unchallenged. In the 
unvaccinated, MG-challenged group 8 the birds displayed $83 \%$ ciliary activity, indicating that MG strain B2159/13 had a minimal effect on tracheal ciliary activity day 12 post-challenge. Interestingly, birds vaccinated with either ts-11 (group 1) or 6/85 (group 5) that were challenged with IBV, displayed low ciliary activity (16\%) compared to unvaccinated IBV control group $7(0 \%)$, suggestive of a partial, non-specific protection. Both dual infected groups 2 and 6 showed no ciliary motility which stresses the longer-term potential negative impact of multiple respiratory pathogens infection, taking into account that only $20 \%$ showed clinical signs over the duration of the scoring period.

Histopathology. Generally, no significant histological differences in the bursae were observed between the different treatment groups including those with macroscopically atrophic bursae in group 4. All birds had moderate lymphocyte depletion with a scores of 2 compared to the normal control samples, although this was likely due to stress.

Tracheas of birds in the vaccinated groups displayed no significant histopathological changes $(\mathrm{P}>0.05)$ prior to challenge, but groups 2 and 6 displayed mild tracheitis with lesion scores of 0.5 (Table 2), characterised by mild expansion of the tracheal mucosa due to diffused lymphocytic infiltration. This might be due to birds' individual differences as group 1, 3 and 5 which received similar vaccinations did not manifest similar lesions.

After challenge, more severe tracheitis characterised by epithelial hyperplasia, lymphoplasmatic infiltration, and decreased mucous cells in most of the birds, especially on day 28 (7 days post MG challenge) were recorded. The lesions increased in severity up until day 33, with marked thickening and expansion of the tracheal mucosa accompanied by epithelial degeneration and deciliation, and lymphocytic and mononuclear cells infiltration, especially in the unvaccinated, co-challenged group 4 (supplemental figure 1). Irrespective of whether or not birds were vaccinated, groups that were challenged either with IBV alone or 
co-challenged (MG and IBV), achieved significantly higher $(\mathrm{P} \leq 0.05)$ scores for tracheal lesions and thickening compared to control group 9. In fact, group 2 (ts-11-vaccinated, cochallenged) recorded the highest tracheal lesion scores with values that were significantly higher $(\mathrm{P}<0.05)$ than those of group $6(6 / 85$-vaccinated, MG+IBV challenged $)$ and the unvaccinated group 4, especially on days 28 and 31. By day 33, the tracheal lesion scores in these three groups (2, 4 and 6) had reached a similar range. Similarly, mean mucosal thickness scores were highest in ts-11 vaccinated group 2 on day 31 (Table 2), followed by unvaccinated control group 4, and lower scores were recorded for the 6/85-vaccinated groups. By day 33, mean thickness scores for these three groups (2, 4 and 6) were lower and similar, yet remained significantly higher than those of groups 1 and 5 (vaccinated against MG, challenged with only IBV), which illustrates the cumulative negative effects of co-infection. In comparison the MG challenge control, group 8, with mean mucosal thickness scores of less than $100 \mu \mathrm{m}$ across all sampling points also underscores the effects of co-infection in the other groups, most of which had higher scores.

Lungs of birds sampled post-vaccination were free of any lesions except for groups 2 (ts-11) and $6(6 / 85)$ whose lungs had lymphoplasmacytic bronchitis characterised by very slight diffused lymphocytic infiltration (data not shown), whereas birds of group 1, 3 and 5 which received similar vaccination did not manifest such lesions.

Tissue distribution and quantitation of MG and IBV. Quantitative rt-PCR and qRT-PCR was used to quantify MG and IBV genomic copies respectively in necropsied tissues collected on days 28, 31 and 33. Primers and probes were designed and validated to differentially detect the challenge pathogens, but not vaccines. Quantitative rt-PCR results for the groups challenged with MG (2, 4, 6 and 8) are presented in Table 3, with qRT-PCR results for IBV provided as supplemental data. The MG challenge strain had colonised all 
Table 3: Mycoplasma gallisepticum challenge strain mean genome copy numbers as determined by quantitative PCR

\begin{tabular}{|c|c|c|c|c|c|c|c|c|c|c|}
\hline \multirow[b]{2}{*}{ Time point } & \multirow[b]{2}{*}{ Treatment group } & \multicolumn{9}{|c|}{ Organ pool } \\
\hline & & Tracheas & Lungs & Air sacs & Kidneys & Livers & Bursae & C. tonsils & Spleens & Hearts \\
\hline $\begin{array}{c}\text { Day } 28 \\
7 d p c M G\end{array}$ & $\mathbf{8}_{\text {unvaccinated, } M G \text { challenged }}$ & $\begin{array}{r}610.6 \\
\pm 863.5\end{array}$ & $\begin{array}{r}1,558.7 \\
\pm 1,699.5\end{array}$ & $\begin{array}{c}1,123 \\
\pm 1,588.2\end{array}$ & $\begin{array}{r}196.7 \\
\pm 106.7\end{array}$ & $\begin{array}{r}290.3 \\
\pm 237.9\end{array}$ & $\begin{array}{r}387.2 \\
\pm 374.1\end{array}$ & $\begin{array}{r}138.9 \\
\pm 196.5\end{array}$ & $\begin{array}{l}106.5 \\
\pm 4.4\end{array}$ & 0 \\
\hline $2 d p c I B V$ & 4 unvaccinated, MG+IBV challenged & $\begin{array}{r}798.8 \\
\pm 1,129.6\end{array}$ & $\begin{array}{r}784.9 \\
\pm 688.8\end{array}$ & $\begin{array}{r}313.4 \\
\pm 358.3\end{array}$ & 0 & $\begin{array}{l}2,244.4 \\
\pm 2,729.9\end{array}$ & $\begin{array}{r}64.46 \\
\pm 91.16\end{array}$ & 0 & 0 & $\begin{array}{c}87 \\
\pm 10.8\end{array}$ \\
\hline & 2 ts-11 vaccinated, $\mathrm{MG}+\mathrm{IBV}$ challenged & $\begin{array}{l}126.4 \\
\pm 70.3\end{array}$ & $\begin{array}{r}728.7 \\
\pm 851.0\end{array}$ & $\begin{array}{l}1,013.6 \\
\pm 1,433.5\end{array}$ & $\begin{array}{r}263.4 \\
\pm 372.5\end{array}$ & 0 & 0 & $\begin{array}{r}25.8 \\
\pm 36.5\end{array}$ & $\begin{array}{r}40.5 \\
\pm 57.3\end{array}$ & $\begin{array}{c}32 \\
\pm 45.4\end{array}$ \\
\hline & $\mathbf{6}_{6 / 85}$ vaccinated, $\mathrm{MG}+\mathrm{IBV}$ challenged & $\begin{array}{r}2,134.6 \\
\pm 3,018.8\end{array}$ & $\begin{array}{c}561 \\
\pm 643.4\end{array}$ & $\begin{array}{r}1,069.4 \\
\pm 1,297.3\end{array}$ & $\begin{array}{r}189.2 \\
\pm 143.1\end{array}$ & $\begin{array}{r}157.1 \\
\pm 222.1\end{array}$ & $\begin{array}{r}60.7 \\
\pm 85.8\end{array}$ & $\begin{array}{l}19.8 \\
\pm 28\end{array}$ & 0 & $\begin{array}{r}560.1 \\
\pm 792.2\end{array}$ \\
\hline $\begin{array}{c}\text { Day } 31 \\
10 d p c M G\end{array}$ & $\mathbf{8}_{\text {unvaccinated, } M G \text { challenged }}$ & $\begin{array}{l}4,405.5 \\
\pm 6,044.7\end{array}$ & $\begin{array}{r}23,956 \\
\pm 33,485\end{array}$ & $\begin{array}{r}2,443.2 \\
\pm 3,071.5\end{array}$ & $\begin{array}{r}3,370.6 \\
\pm 2,208.9\end{array}$ & $\begin{array}{r}24,899.5 \\
\pm 13,659.9\end{array}$ & $\begin{array}{l}2,525.6 \\
\pm 1,179.1\end{array}$ & $\begin{array}{r}12,685.7 \\
\pm 1,331\end{array}$ & $\begin{array}{r}997.5 \\
\pm 1,261.8\end{array}$ & $\begin{array}{r}1,063.6 \\
\pm 1,504.1\end{array}$ \\
\hline $5 d p c I B V$ & 4 unvaccinated, MG+IBV challenged & $\begin{array}{r}37,848.5 \\
\pm 42,584\end{array}$ & $\begin{array}{r}293,525 \\
\pm 397,251.1\end{array}$ & $\begin{array}{r}41,092.8 \\
\pm 4,147.7\end{array}$ & $\begin{array}{r}11,763.5 \\
\pm 13,714.4\end{array}$ & $\begin{array}{r}945.5 \\
\pm 1,158.9\end{array}$ & $\begin{array}{r}817.5 \\
\pm 590\end{array}$ & $\begin{array}{r}386.6 \\
\pm 404.8\end{array}$ & $\begin{array}{r}933.4 \\
\pm 910.5\end{array}$ & $\begin{array}{r}62.3 \\
\pm 88.1\end{array}$ \\
\hline & $\mathbf{2}_{\text {ts-11 vaccinated, MG+IBV challenged }}$ & $\begin{array}{r}1,717 \\
\pm 1,116.8\end{array}$ & $\begin{array}{l}870,112.5 \\
\pm 266,154.6\end{array}$ & $\begin{array}{r}1,589.4 \\
\pm 170.8\end{array}$ & $\begin{array}{r}57,251.1 \\
\pm 79,111.9\end{array}$ & $\begin{array}{l}15,438.1 \\
\pm 1,662.4\end{array}$ & $\begin{array}{r}2,094.3 \\
\pm 2,639.4\end{array}$ & $\begin{array}{l}1,859.1 \\
\pm 1,820.1\end{array}$ & $\begin{array}{r}146.4 \\
\pm 207.1\end{array}$ & $\begin{array}{r}98.3 \\
\pm 17.4\end{array}$ \\
\hline & $\mathbf{6}_{6 / 85}$ vaccinated, $\mathrm{MG}+\mathrm{IBV}$ challenged & $\begin{array}{l}5,620.8 \\
\pm 6,850.9\end{array}$ & $\begin{array}{l}12,103.1 \\
\pm 14,604.6\end{array}$ & $\begin{array}{r}14,212 \\
\pm 14,215.4\end{array}$ & $\begin{array}{l}35,185.2 \\
\pm 31,040.1\end{array}$ & $\begin{array}{r}5,711.8 \\
\pm 5,735.0\end{array}$ & $\begin{array}{l}11,059.5 \\
\pm 6,637.5\end{array}$ & $\begin{array}{l}1,321.1 \\
\pm 1,481.5\end{array}$ & $\begin{array}{r}612.8 \\
\pm 802.4\end{array}$ & $\begin{array}{r}542.2 \\
\pm 287.8\end{array}$ \\
\hline Day 33 & 8 unvaccinated, MG challenged & 0 & $\begin{array}{r}231.2 \\
\pm 191.3\end{array}$ & 0 & $\begin{array}{r}303.1 \\
\pm 140.9\end{array}$ & $\begin{array}{r}84.1 \\
\pm 118.9\end{array}$ & $\begin{array}{r}21,744.1 \\
\pm 30,750.8\end{array}$ & $\begin{array}{r}96.8 \\
\pm 136.9\end{array}$ & 0 & $\begin{array}{r}8,324.2 \\
\pm 296.8\end{array}$ \\
\hline
\end{tabular}




\begin{tabular}{|c|c|c|c|c|c|c|c|c|c|c|}
\hline \multirow[t]{3}{*}{$\begin{array}{c}12 d p c M G \\
7 d p c I B V\end{array}$} & 4 unvaccinated, MG+IBV challenged & 0 & $\begin{array}{r}83.4 \\
\pm 118\end{array}$ & $\begin{array}{r}232.7 \\
\pm 175.0\end{array}$ & $\begin{array}{l}531,036.7 \\
\pm 55,600.4\end{array}$ & $\begin{array}{l}64,493.2 \\
\pm 11,744.1\end{array}$ & $\begin{array}{l}138.8 \\
\pm 31.4\end{array}$ & 0 & $\begin{array}{r}251.5 \\
\pm 197.5\end{array}$ & 0 \\
\hline & 2 ts-11 vaccinated, MG+IBV challenged & $\begin{array}{r}268.9 \\
\pm 133.8\end{array}$ & $\begin{array}{l}241,297.3 \\
\pm 27,164.1\end{array}$ & $\begin{array}{l}1,886.5 \\
\pm 436.3\end{array}$ & 0 & $\begin{array}{l}4,356.8 \\
\pm 940.9\end{array}$ & 0 & 0 & 0 & $\begin{array}{r}283.9 \\
\pm 199.6\end{array}$ \\
\hline & $\mathbf{6}_{6 / 85}$ vaccinated, $M G+I B V$ challenged & 0 & 0 & $\begin{array}{l}45.7 \\
\pm 64.6\end{array}$ & 0 & $\begin{array}{l}2,689.4 \\
\pm 753.7\end{array}$ & $\begin{array}{l}549,959.8 \\
\pm 59,680.1\end{array}$ & $\begin{array}{l}76,003.2 \\
\pm 6,548.4\end{array}$ & $\begin{array}{l}147.1 \\
\pm 23.2\end{array}$ & $\begin{array}{r}703.8 \\
\pm 616.3\end{array}$ \\
\hline
\end{tabular}

$<100$ genome copies

100-1,000 genome copies

1,000-10,000 genome copies

10,000-100,000 genome copies

$>100,000$ genome copies

MG: Mycoplasma gallisepticum

IBV: infectious bronchitis virus 
tissues examined (trachea, lungs, air sacs, kidney, liver, bursa of Fabricius, caecal tonsils, spleen and heart), but copy amounts varied substantially across the sampling period and groups. Generally, the highest MG genome copy numbers were detected on day 31 . The genome copy categories are shaded in Table 3. Although efforts were made to avoid crosscontamination during necropsy and whilst performing PCR, we thus considered genomic copy numbers $>0$ but $<100$ to be possible PCR contamination.

MG replication in the respiratory organs. In the tracheas, unvaccinated group 4 that had been challenged with both pathogens had the highest MG load at almost 38,000 genome copies detected on day 31, but no IBV was present (supplemental data). Although the tracheal lesion scores had been relatively lower in this group (Table 2), the mean mucosal thickness was higher than most groups, apart from group 2. Thus, in group 4, the inflammation observed in the trachea on day 31 was primarily due to high levels of MG replication. Although the virus itself was not detected, IBV co-infection appeared to enhance MG replication in group 4 on day 31, since group 8, challenged with MG alone, had 8-fold fewer mean MG copy numbers. The value of a co-challenge model becomes apparent as the effects of the respective vaccines on MG copy number are more easily distinguishable: compared to group 4, the ts-11 vaccinated co-infected group 2 showed a 22 -fold reduction in MG mean copy number in the tracheas, whereas in 6/85-vaccinated and co-challenged group 6 , vaccinated, the reduction in replication was only about 6-fold. In spite of the dramatic reduction of MG mean genome copies in the ts-11 vaccinated group 2, the IBV mean genome copies in the trachea on day 31 was excessively high with a mean of over 3.2 million viral genomes copies detected, compared to slightly more moderate IBV levels of 1.7 million copies in group 5 (supplemental data). This difference is reflected in the tracheal lesion scores and in the mean mucosal thickness measurements, where group 2 attained the highest 
values (Table 2). As mentioned above, no IBV was detected in the tracheas in challenge control group 4 on day 31, therefore the effects of the MG vaccines themselves appear to aggravate IBV replication in the tracheas on day 31 , but ts-11 did so to a greater extent. By day 33, MG replication in the tracheas had reduced to zero or negligible levels across all groups.

In the lungs, the MG mean genome copy numbers in unvaccinated group that received only MG (group 8) compared to the unvaccinated group that received both MG and IBV (group 4) were about 12 -fold lower on day 31 . The vaccines had two very different effects on MG replication in the lungs. Whereas 6/85 vaccinated birds (group 6) showed a significant decrease in the levels of MG on day 31 to about 12,000 mean genome copies, the ts- 11 vaccinated birds in group 2 experienced the opposite effect, with more than 870,000 mean MG genome copies detected. This also corresponds to significantly higher levels of IBV in the lungs of group 2's birds on day 31, at roughly 10,000-fold more IBV genomes detected (supplemental data). By day 33, MG and IBV replication levels in the lungs had decreased markedly.

The air sacs were also more heavily colonised by MG on day 31 in co-challenged group 4, compared to group 8 that received $\mathrm{MG}$ alone. More than 5.2 million mean IBV genome copies were detecting in co-challenged group 4 on day 31, whereas across all other IBVinfected groups, this number was $<245$. On day 31 , the ts- 11 vaccine was more successful in reducing the MG load in the air sacs from > 41,000 mean copies to a mean of just 1,589 , compared to the $6 / 85$ vaccinated birds, where 14,212 mean copies were recorded. MG levels in the air sacs continued to fall on day 33. The IBV genome copies were also significantly higher in the co-challenged group 4 and 6 on day 31, while group 6 had a generally significantly higher $(\mathrm{P}<0.05)$ level of genomic copies on days 28,31 and 33 in comparison to the other groups including the IBV positive control group 7 (unvaccinated, IBV 
challenged), thus suggesting that the non-specific immune responses activated by the $6 / 85$ vaccine was less robust in the air sacs.

MG replication in other organs. MG replication levels on day 31 in the kidneys of both vaccinated groups was higher than the control $(11,763)$ at values of 57,251 for ts-11 and 35,185 for 6/95. This did not appear to be linked to IBV replication in these tissues (supplemental data). By day 33, MG in the kidneys had increased substantially to mean levels of $>531,000$ organisms, but no MG was detected in either of the vaccinated groups. It is interesting that the highest mean numbers of IBV in the kidneys, at $>812,000$ viral genomes, was detected in group 1 (ts-11 vaccinated, IBV challenged), corresponding with lung numbers (supplemental data).

In contrast to the ts-11 vaccine's seemingly weaker ability to decrease MG replication in the lungs, air sacs and livers, in the bursae this vaccine was highly successful in reducing MG replication on day 33 , since in the 6/85 vaccinated group, an excessively high amount of MG genome copies were detected, although no significant differences in relation to the macro and microscopic lesions observed in these groups. The mean values greater than 2000, 549,000, and 140 copies in the liver, bursae and spleen respectively were significantly $(\mathrm{P}<0.05)$ higher than that of their control group. Similarly, in the caecal tonsils, the $6 / 85$ vaccine appeared to promote bacterial replication on day 33 whereas the ts-11 vaccine decreased MG genome copy levels to 0 . The combination of vaccination with virulent $\mathrm{MG}$ and IBV challenge caused dramatic increases on day 31 of IBV genomes in the livers and bursae of 6/85-vaccinated birds, and in the bursae, caecal tonsils, spleens and hearts of ts-11 vaccinated birds (supplemental data). This interesting phenomenon warrants further investigation. 


\section{DISCUSSION}

The presence of genetically unique MG strains in South Africa (Armour et al., 2013; Bwala, 2017), and field reports of sub-optimal vaccine protection prompted us to investigate the protective efficacy of ts-11 and 6/85 MG vaccines against a local virulent MG field strain, B2159/13. To enhance clinical symptoms and mimic a typical field situation, we co-infected birds with a virulent strain of QX-like IBV. Previous MG co-challenge models have either used NDV and/or IBV vaccines (Rodriguez \& Kleven, 1980, Nakamura et al., 1994, Leigh et al., 2012), or other pathogens like H3N8 influenza virus (Stipkovitz et al., 2012) and E.coli (Nakamura et al., 1994). To our knowledge, this is the first time that virulent MG and IBV have been co-infected to assess vaccine efficacy.

Both vaccines showed similar ability to protect infected chickens from clinical signs; and post mortem lesions as well as ciliary motility scores were also comparable. Birds vaccinated with the 6/85 vaccine had significantly lower tracheal lesion scores and mucosal thickness at day 28 and day 31 compared to ts- 11 vaccinated birds, but the difference was insignificant at day 33. Notable differences between the two vaccines were evident in their ability to protect against MG replication. The 6/85 vaccine produced a more significant reduction in $\mathrm{MG}$ replication in the lungs, kidneys and livers but appeared to enhance late replication in bursae and caecal tonsils. The ts-11 vaccine in contrast appeared to have a more pronounced effect on replication in tracheas, air sacs, bursae and heart at day 28 and day 31 but increased replication in lungs. The ability of ts-11 to more effectively reduce MG replication in the tracheas compared to 6/85 did not correlate with the mean tracheal lesion or mucosal thickness scores, but when IBV replication is taken into account, ts-11 vaccination appeared to promote IBV replication in the tracheas.

The observed propensity of ts-11 vaccination to promote lower respiratory tract replication of MG in combination with IBV, contrasted with propensity of $6 / 85$ to promote later replication 
of $\mathrm{MG}$ in the caecal tonsils, raises an interesting question about how vaccine choice might affect main shedding routes of MG challenge in the field.

Some workers have reported the localization of MG antigen by immunohistochemistry to the trachea and the major airways in the chicken lungs, with no detectable mycoplasma in the pulmonary parenchyma and all the non-respiratory tissues examined (brain, heart, liver, spleen, kidney, duodenum, pancreas, proventriculus, gizzard, thymus, caecal tonsil, bursa of Fabricius, testes and ovary) (Gharaibeh \& Hailat, 2011). However, our results showing that MG is able to colonise multiple organs are supported by those of Stipkovitz et al. (2012) who performed a co-challenge study involving MG and an H3N8 influenza A virus strain. MG was re-isolated from respiratory organs, liver, spleen, kidney and heart, and similar to our detection data, recovery rates were higher in the co-infected group.

Some very interesting interactions between the pathogens were observed that warrant further investigation. Both vaccines provided a low non-specific protection against IBV challenge as was evident in the clinical signs, ciliary motility and the viral load in some tissues of IBV challenged groups vaccinated with the two MG vaccines. Groups 1 (ts-11 vaccinated, IBV challenged) had no diseased birds whereas group 5 (6/85 vaccinated, IBV challenged) had only $10 \%$ diseased birds compared to $40 \%$ observed in the unvaccinated group challenged with IBV (group 7). Similar results were recorded in the ciliostasis assay where groups 1 and 5 had $16 \%$ ciliary activity compared to $0 \%$ ciliary activity in group 7 . Where tissue distribution of pathogens was assessed on day 33, group 1 (ts-11 vaccinated, IBV challenged) and group 5 (6/85 vaccinated, IBV challenged) had IBV levels of around 4,000 and 30 genome copies respectively, compared to unvaccinated, IBV-challenged group 7, with mean IBV levels approaching 58,000 genome copies (supplemental data). Similarly, decreased IBV levels were detected in the lungs and caecal tonsils of both group 1 and group 5's birds, compared to group 7. 
MG ELISA results were negative (data not shown), thus protection offered by the two vaccines was not dependent on the production and level of systemic circulating antibodies, which is consistent with earlier reports (Noormohammadi et al., 2002; Whithear, 1996). Instead, other factors such as antibodies ( $\operatorname{IgA})$ in the respiratory secretions and the cellmediated immune system, i.e. natural killer cells and cytotoxic-T cell responses are likely involved in controlling and inhibition of $\mathrm{MG}$ colonisation and attachment to tracheal epithelial cells, and it is likely that these components were also responsible for the nonspecific immune responses and partial protection against IBV (Talkington \& Kleven, 1985; Yagihashi \& Tajima, 1986; Avakian \& Ley, 1993a,b; Javed et al., 2005; Gaunson et al., 2000, 2006).

The co-challenge model provided useful data on vaccine efficacy, especially on days 31 and 33, and tracheas, lungs, air sacs, kidneys, liver and caecal tonsils were the best organs to assess. Our results reflect the complexity of both the host's immune mechanisms and the pathogen itself. Polar effects of MG infection and vaccines on co-infecting pathogens were also shown; in either the aggravation or promotion of IBV replication, or indeed, non-specific protection by the vaccines against IBV infection.

\section{Acknowledgements}

DGB was a recipient of a University of Pretoria scholarship. This work was funded by CA's Inventive Fund for Rated Researchers grant from South Africa's National Research Foundation. We thank Johan Gouws, Karen Ebersohn and Pamela Wambulawaye for technical support, and Rainbow Laboratories for use of the IBV challenge strain.

\section{Disclosure statement}

No potential conflict of interest was reported by the authors 


\section{REFERENCES}

Abd-El-Motelib, T.Y. \& Kleven, S.H. (1993). A comparative study of Mycoplasma gallisepticum vaccines in young chickens. Avian Diseases, 37, 981-987.

Abolnik, C. (2015). Genomic and single nucleotide polymorphism analysis of infectious bronchitis coronavirus. Infection, Genetic and Evolution, 32, 416-424.

Adler, H.E., McMartin, D. \& Shifrine, M. (1960). Immunization against Mycoplasma infections of poultry. The American Journal of Veterinary Research, 21, 482-485.

Armour, N.K., Laibinis, V.A., Collett, S.R. \& Ferguson-Noel, N. (2013). The development and application of a Mycoplasma gallisepticum sequence database. Avian Pathology, 42, 408-415.

Avakian, A.P. \& Ley, D.H. (1993a). Protective immune response to Mycoplasma gallisepticum demonstrated in respiratory-tract washings from M. gallisepticum-infected chickens. Avian Diseases, 37, 697-705.

Avakian, A.P. \& Ley, D.H. (1993b). Inhibition of Mycoplasma gallisepticum growth and attachment to chick tracheal rings by antibodies to a 64-kilodalton membrane protein of M. gallisepticum. Avian Diseases, 37, 706-714.

Bancroft, J.D. \& Gamble, M. (2008). Theory and Practice of Histological Techniques. Philadelphia, PA: Churchill Livingstone/Elsevier Health Science.

Bwala, D.G. (2017). Mycoplasma gallisepticum infection dynamics and vaccine protection in South African poultry. PhD dissertation. (pp.40-69). University of Pretoria. Available at: URL pending. 
Dean, A.G., Sullivan, K.M. \& Soe, M.M. (2013). OpenEpi Version 3.0.1: Open Source Epidemiologic statistics for public health. Updated April 6, 2013. Available at: www.OpenEpi.com/, accessed 02/08/2016.

Evans, R.D. \& Hafez, Y.S. (1992). Evaluation of a Mycoplasma gallisepticum strain exhibiting reduced virulence for prevention and control of poultry mycoplasmosis. Avian Disease, $36,197-201$.

Gaunson, J. E., Philip, C. J., Whithear, K. G. \& Browning, G. F. (2000). Lymphocytic infiltration in the chicken trachea in response to Mycoplasma gallisepticum infection. Microbiology Reading, 146, 1223-1229.

Gaunson, J.E., Philip, C.J., Whithear, K.G. \& Browning, G.F. (2006). The cellular immune response in the tracheal mucosa to Mycoplasma gallisepticum in vaccinated and unvaccinated chickens in the acute and chronic stages of disease. Vaccine, 24, 26272633.

Gharaibeh, S. \& Hailat, A. (2011). Mycoplasma gallisepticum experimental infection and tissue distribution in chickens, sparrows and pigeons. Avian Pathology, 40, 349-354.

Hudson, P., Gorton, T.S., Papazisi, L., Cecchini, K., Frasca, J.S. \& Geary, S.J. (2006). Identification of a virulence-associated determinant, dihydrolipoamide dehydrogenase (lpd), in Mycoplasma gallisepticum through in vivo screening of transposon mutants. Infection and Immunity, 74, 931-939.

Javed, M.A., Frasca, J.S., Rood, D., Cecchini, K., Gladd, M., Geary, S.J. \& Silbart, L.K. (2005). Correlates of immune protection in chickens vaccinated with Mycoplasma gallisepticum 
strain GT5 following challenge with pathogenic M. gallisepticum strain Rlow. Infection and immunity, 73, 5410-5419.

Knoetze, A.D., Moodley, N.M. \& Abolnik, C. (2014). Two genotypes of infectious bronchitis virus are responsible for serological variation in KwaZulu-Natal poultry flocks prior to 2012. Onderstepoort Journal of Veterinary Research, 81, 1-10.

Leigh, S.A., Branton, S.L., Evans, J.D. \& Collier, S.D. (2012). Effect of infection route and concurrent infectious bronchitis virus vaccination on Mycoplasma gallisepticum disease pathology in an experimental model. Avian Pathology, 41, 497-503.

Luginbuhl, R.E., Tourtellotte, M.E. \& Frazier, M.N. (1967). Mycoplasma gallisepticum control by immunization. Annals of the New York Academy of Sciences, 143, 234-238.

Muskett, J.C., Hopkins, I.G., Edwards, K.R. \& Thornton, D.H. (1979). Comparison of two infectious bursal disease vaccine strains: efficacy and potential hazards in susceptible and maternally immune birds. Veterinary Record, 104, 332-334.

Nakamura, K., Ueda, H., Tanimura, T. \& Noguchi, K. (1994). Effect of mixed live vaccine (Newcastle disease and infectious bronchitis) and Mycoplasma gallisepticum on the chicken respiratory tract and on Escherichia coli infection. Journal of Comparative Pathology, 111, 33-42.

Naylor, C.J., Al-Ankari, A.R., Al-Afaleq, A.I, Bradbury, J.M \& Jones, R.C. (1992). Exacerbation of Mycoplasma gallisepticum infection in turkeys by rhinotracheitis virus. Avian Pathology, 21, 295-305.

Noormohammadi, A.H., Jones, J.F. Underwood, G. \& Whithear, K.G. (2002). Poor systemic antibody response after vaccination of commercial broiler breeders with Mycoplasma 
gallisepticum vaccine ts-11 not associated with susceptibility to challenge. Avian Diseases, 46, 623-628.

Nunoya, T., Tajima, M., Yagihashi, T. \& Sannai, S. (1987). Evaluation of respiratory lesions in chickens induced by Mycoplasma gallisepticum. Japanese Journal of Veterinary Science, 49, 621-629.

OIE (World Organisation for Animal Health) (2008). Avian mycoplasmosis (Mycoplasma gallisepticum, M, synoviae) in Manual of Diagnostic Tests and Vaccines for Terrestrial Animals (mammals, birds and bees), Chapter 2. 3. 5. $6^{\text {th }}$ Edition. Paris, France: Office International Des Epizooties.

Rodriguez, R. \& Kleven, S.H. (1980). Evaluation of a vaccine against Mycoplasma gallisepticum in commercial broilers. Avian Diseases, 24, 879-889.

Stipkovitz, L., Egyed, L., Palfi, V., Beres, A., Pitlik, E., Somogyi, M., Szathmary, S. \& Denes, B. (2012). Effect of low-pathogenicity influenza virus H3N8 infection on Mycoplasma gallisepticum infection of chickens. Avian Pathology, 41, 51-57.

Talkington, F.D. \& Kleven, S.H. (1985). Evaluation of protection against colonization of the chicken trachea following administration of Mycoplasma gallisepticum bacterin. Avian Diseases, 29, 998-1003.

Whithear, K.G. (1996). Control of avian mycoplasmoses by vaccination. Revue Scientifique et Technique, 15, 1527-1553.

Yagihashi, T. \& Tajima, M. (1986). Antibody responses in sera and respiratory secretions from chickens infected with Mycoplasma gallisepticum. Avian Diseases, 30, 543-550. 


\section{Supplementary material}

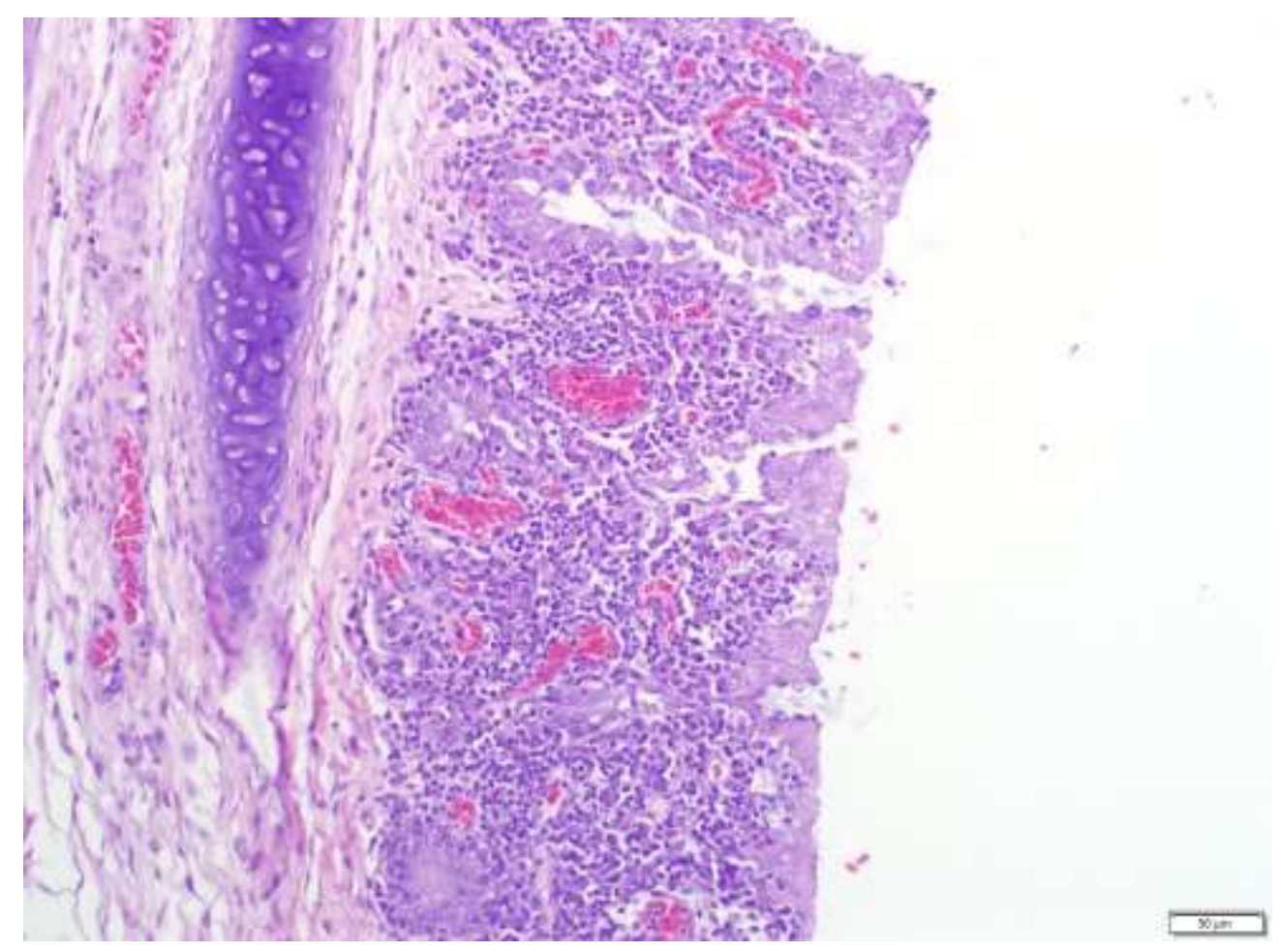

Supplemental Figure 1. Trachea with thickened mucosa, epithelial degeneration and lymphoplasmacytic and mononuclear cell infiltration, from an unvaccinated bird challenged

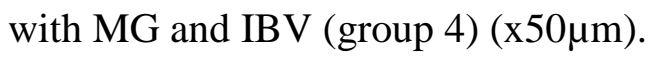




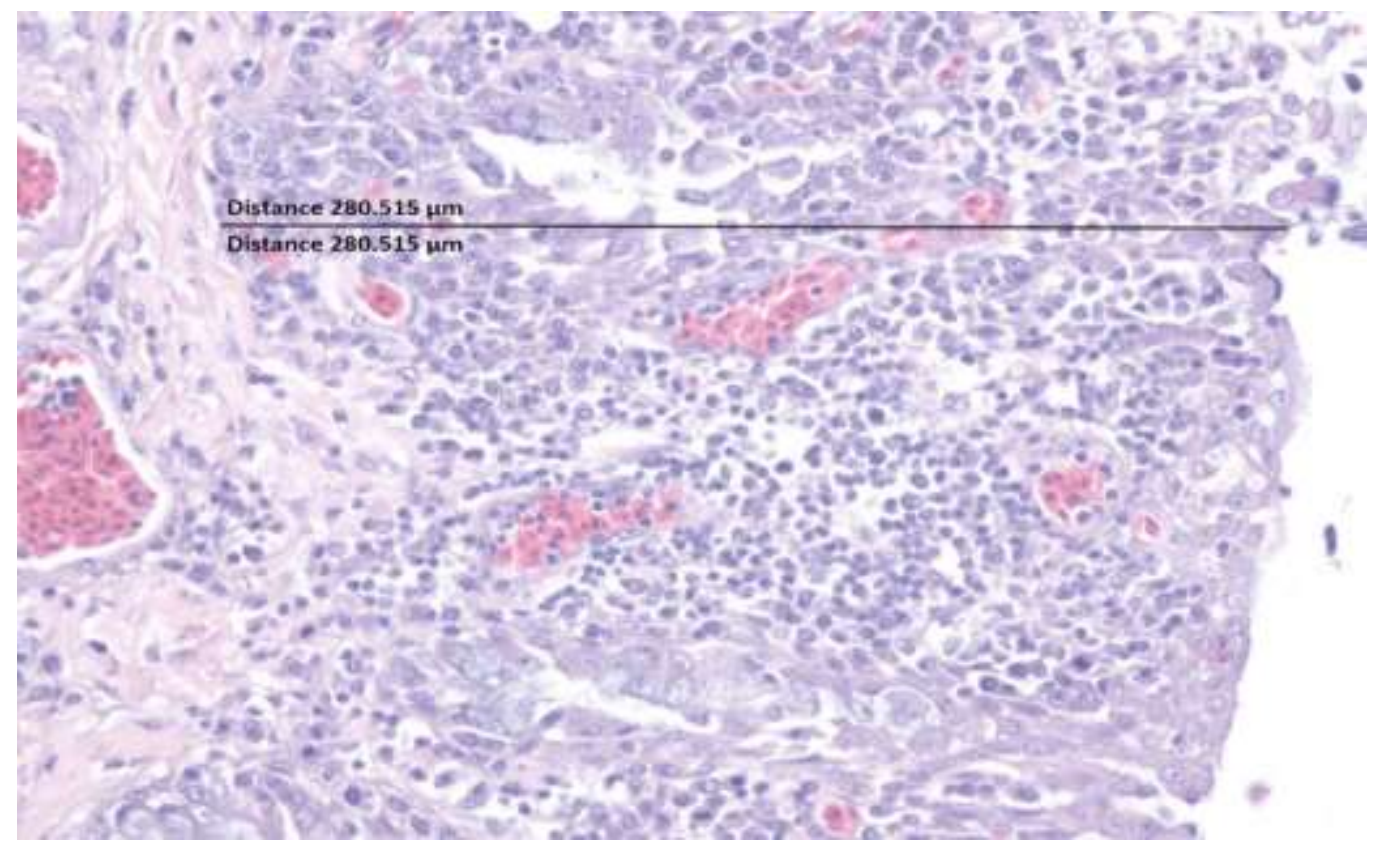

Supplemental Figure 2. Severe mucosal thickening in the trachea resulting from a diffuse lymphoplasmacytic and mononuclear cells infiltration of the lamina propria, in an unvaccinated bird challenged with both $\mathrm{MG}$ and IBV (group 4) (20x magnification). A normal trachea from an unvaccinated, unchallenged negative control bird had a mucosal thickness of about $33 \mu \mathrm{m}$ with no cellular infiltration of the lamina propria (not shown). 
Supplemental Table: Infectious bronchitis virus mean genome copy numbers as determined by quantitative RT-PCR

\begin{tabular}{|c|c|c|c|c|c|c|c|c|c|c|}
\hline \multirow[b]{2}{*}{ Time point } & \multirow[b]{2}{*}{$\begin{array}{c}\text { Treatment } \\
\text { group }\end{array}$} & \multicolumn{9}{|c|}{ Organ pools tested } \\
\hline & & Tracheas & Lungs & Air sacs & Kidneys & Livers & Bursae & C. tonsils & Spleens & Hearts \\
\hline \multirow{6}{*}{$\begin{array}{c}\text { Day } 28 \\
7 d p c M G \\
2 d p c I B V\end{array}$} & $\begin{array}{l}\mathbf{7}_{\text {unvaccinated, IBV }} \\
\text { challenged }\end{array}$ & $\begin{array}{l}17.1 \\
\pm 0.6\end{array}$ & 0 & $\begin{array}{c}883.8 \\
\pm 1,047.0\end{array}$ & $\begin{array}{l}624.8 \\
\pm 35.5\end{array}$ & $\begin{array}{r}347.2 \\
\pm 334.0\end{array}$ & $\begin{array}{l}2,701.8 \\
\pm 1,898.8\end{array}$ & $\begin{array}{c}347,474.9 \\
\pm 65,802\end{array}$ & $\begin{array}{l}1,592.9 \\
\pm 1042.8\end{array}$ & $\begin{array}{l}1,124.3 \\
\pm 418.3\end{array}$ \\
\hline & $\begin{array}{l}\mathbf{4}_{\text {unvaccinated, } \mathrm{MG}+\mathrm{IBV}} \\
\text { challenged }\end{array}$ & 0 & 0 & $\begin{array}{r}54.6 \\
\pm 18.6\end{array}$ & $\begin{array}{r}1.71 \\
\pm 2.41\end{array}$ & $\begin{array}{r}1.7 \\
\pm 2.4\end{array}$ & 0 & 0 & 0 & 0 \\
\hline & $\begin{array}{l}\mathbf{1}_{\mathrm{ts}-11 \text { vaccinated, IBV }} \\
\text { challenged }\end{array}$ & $\begin{array}{l}33,998.2 \\
\pm 16,461.5\end{array}$ & $\begin{array}{r}4.9 \\
\pm 6.9\end{array}$ & $\begin{array}{c}4.9 \\
\pm 7.0\end{array}$ & 0 & 0 & 0 & 0 & $\begin{array}{r}21.5 \\
\pm 11.7\end{array}$ & 0 \\
\hline & $\begin{array}{l}\mathbf{2}_{\mathrm{ts}-11 \text { vaccinated, }} \\
\text { MG+IBV challenged }\end{array}$ & $\begin{array}{r}46.8 \\
\pm 3.2\end{array}$ & $\begin{array}{c}17,086.6 \\
\pm 969.1\end{array}$ & $\begin{array}{l}14.8 \\
\pm 3.0\end{array}$ & 0 & 0 & 0 & 0 & 0 & $\begin{array}{l}22.7 \\
\pm 21.7\end{array}$ \\
\hline & $\begin{array}{l}\mathbf{5}_{6 / 85} \text { vaccinated, IBV } \\
\text { challenged }\end{array}$ & 0 & $\begin{array}{l}263.5 \\
\pm 56.1\end{array}$ & $\begin{array}{r}54.9 \\
\pm 3.0\end{array}$ & $\begin{array}{r}42.6 \\
\pm 28.3\end{array}$ & $\begin{array}{l}15,681.1 \\
\pm 16,066.9\end{array}$ & 0 & 0 & 0 & 0 \\
\hline & $\begin{array}{l}\mathbf{6}_{6 / 85} \text { vaccinated, } \\
\text { MG+IBV challenged }\end{array}$ & $\begin{array}{r}30.9 \\
\pm 28.1\end{array}$ & $\begin{array}{c}97 \\
\pm 40.8\end{array}$ & $\begin{array}{c}962.3 \\
\pm 1,178.7\end{array}$ & $\begin{array}{r}55.3 \\
\pm 36.5\end{array}$ & $\begin{array}{r}76.3 \\
\pm 23.8\end{array}$ & $\begin{array}{c}106,074.2 \\
\pm 38,958\end{array}$ & $\begin{array}{r}3.0 \\
\pm 4.2\end{array}$ & 0 & $\begin{array}{c}0.9 \\
\pm 1.2\end{array}$ \\
\hline \multirow{6}{*}{$\begin{array}{c}\text { Day } 31 \\
10 d p c M G \\
5 d p c I B V\end{array}$} & $\begin{array}{l}\mathbf{7}_{\text {unvaccinated, IBV }} \\
\text { challenged }\end{array}$ & $\begin{array}{l}4,782.3 \\
\pm 6,022.2\end{array}$ & $\begin{array}{l}1,148.2 \\
\pm 634.6\end{array}$ & $\begin{array}{l}179 \\
\pm 3.1\end{array}$ & $\begin{array}{l}265.1 \\
\pm 79.6\end{array}$ & $\begin{array}{l}5,860,768 \\
\pm 8,288,280\end{array}$ & $\begin{array}{l}412.8 \\
\pm 16.3\end{array}$ & $\begin{array}{l}2,683.9 \\
\pm 638.2\end{array}$ & $\begin{array}{l}181.2 \\
\pm 78.0\end{array}$ & $\begin{array}{l}15,528.4 \\
\pm 2,895.2\end{array}$ \\
\hline & $\begin{array}{l}\mathbf{4}_{\text {unvaccinated, } \mathrm{MG}+\mathrm{IBV}} \\
\text { challenged }\end{array}$ & 0 & $\begin{array}{r}148.4 \\
\pm 209.9\end{array}$ & $\begin{array}{l}5,242,014.3 \\
\pm 7,413,304.3\end{array}$ & $\begin{array}{r}367,713.4 \\
\pm 519,496.6\end{array}$ & $\begin{array}{l}3,250.4 \\
\pm 1,180.2\end{array}$ & $\begin{array}{l}2,302.7 \\
\pm 2,515\end{array}$ & $\begin{array}{l}1,224,606.5 \\
\pm 1,731,701.3\end{array}$ & $\begin{array}{l}1,372,519.4 \\
\pm 1,940,331.3\end{array}$ & $\begin{array}{c}3,908,696 \\
+5,516,634.3\end{array}$ \\
\hline & $\begin{array}{l}1_{\text {ts-11 vaccinated, IBV }} \\
\text { challenged }\end{array}$ & $\begin{array}{r}618.9 \\
\pm 112.2\end{array}$ & $\begin{array}{c}6,504,120,162 \\
\pm 9,196,998,941.6\end{array}$ & $\begin{array}{r}157.5 \\
\pm 222.7\end{array}$ & $\begin{array}{l}812,670.1 \\
\pm 114,193\end{array}$ & $\begin{array}{r}299.4 \\
\pm 336.1\end{array}$ & $\begin{array}{l}499.1 \\
\pm 241.1\end{array}$ & $\begin{array}{l}25.1 \\
\pm 35.5\end{array}$ & $\begin{array}{l}650,958.3 \\
\pm 920,594\end{array}$ & $\begin{array}{l}4,246,112.5 \\
\pm 6,004,909.9\end{array}$ \\
\hline & $\begin{array}{l}2_{\text {ts-11 vaccinated, }} \\
\text { MG+IBV challenged }\end{array}$ & $\begin{array}{c}3,227,795.6 \pm \\
4,559,427.8\end{array}$ & $\begin{array}{r}629,718.3 \\
\pm 855,601.4\end{array}$ & $\begin{array}{r}175.9 \\
\pm 164.2\end{array}$ & $\begin{array}{r}145.7 \\
\pm 206.0\end{array}$ & $\begin{array}{r}327.4 \\
\pm 119.3\end{array}$ & $\begin{array}{c}8,321,015 \\
\pm 11,767,457.5\end{array}$ & $\begin{array}{l}4,373,684.6 \\
\pm 6,185,178.2\end{array}$ & $\begin{array}{l}1,791,418.8 \\
\pm 2,529,040.2\end{array}$ & $\begin{array}{r}859,092.3 \\
\pm 1,214,940\end{array}$ \\
\hline & $\begin{array}{l}\mathbf{5}_{6 / 85} \text { vaccinated, IBV } \\
\text { challenged }\end{array}$ & $\begin{array}{l}1,712,439 \\
\pm 2413362\end{array}$ & $\begin{array}{r}8.8 \\
\pm 12.2\end{array}$ & $\begin{array}{r}11.4 \\
\pm 16.1\end{array}$ & $\begin{array}{l}1,239.5 \\
\pm 563.6\end{array}$ & $\begin{array}{c}1,258.8 \\
\pm 149.9\end{array}$ & $\begin{array}{c}1,359.1 \\
\pm 33.5\end{array}$ & $\begin{array}{l}1,400.9 \\
\pm 650.3\end{array}$ & $\begin{array}{r}53.4 \\
\pm 75.6\end{array}$ & $\begin{array}{r}461.2 \\
\pm 188.8\end{array}$ \\
\hline & $\mathbf{6}_{6 / 85 \text { vaccinated }}$ & 358.2 & 25.7 & 244.2 & 535.9 & $1,349,379.6$ & $1,418,373.4$ & 730.6 & 5.6 & 492.6 \\
\hline
\end{tabular}




\begin{tabular}{|c|c|c|c|c|c|c|c|c|c|c|}
\hline & $\mathrm{MG}+\mathrm{IBV}$ challenged & \pm 46.4 & \pm 24.4 & \pm 54.9 & \pm 182.6 & $\pm 1,907,752.7$ & $\pm 1,996,371.9$ & \pm 78.9 & \pm 7.9 & \pm 141.6 \\
\hline \multirow{12}{*}{$\begin{array}{c}\text { Day } 33 \\
12 d p c M G \\
7 d p c I B V\end{array}$} & $7_{\text {unvaccinated, IBV }}$ & $57,928.7$ & $19,344.1$ & 510.3 & 724.3 & $3,935.1$ & 733.8 & $21,394.6$ & 569.3 & 0 \\
\hline & challenged & $\pm 80,925.1$ & $\pm 23,531.2$ & \pm 119.9 & \pm 985.1 & \pm 332.8 & \pm 628.7 & $\pm 13,087.8$ & \pm 208.3 & \\
\hline & $\mathbf{4}_{\text {unvaccinated, } M G+I B V}$ & 115.9 & $6,067.5$ & 25.6 & $1,640.3$ & 783.4 & 137.8 & $11,948.8$ & $3,238.6$ & 641 \\
\hline & challenged & \pm 40.5 & $\pm 2,521.3$ & \pm 30.7 & \pm 274.6 & \pm 13.9 & \pm 35.4 & \pm 427.9 & \pm 977.7 & \pm 418.6 \\
\hline & $\mathbf{1}_{\mathrm{ts}-11 \text { vaccinated, IBV }}$ & $3,932.6$ & 56 & 19.0 & 86.5 & $4,316.1$ & 918.5 & $6,106.6$ & $19,545.7$ & 595 \\
\hline & challenged & $\pm 1,802.1$ & \pm 1.9 & \pm 1.5 & \pm 7.0 & \pm 378 & \pm 509.2 & \pm 283.7 & $\pm 8,584.5$ & \pm 364.2 \\
\hline & $\boldsymbol{2}_{\mathrm{ts}-11 \text { vaccinated, }}$ & $4,982.6$ & 814 & 87.0 & 0 & $90,017.8$ & $1,458.7$ & 86.1 & $1,837.9$ & 296.5 \\
\hline & MG+IBV challenged & $\pm 2,705.9$ & \pm 261.5 & \pm 29.9 & & $\pm 2,3247.9$ & $\pm 1,034.3$ & \pm 37.1 & $\pm 1,667.8$ & \pm 22.4 \\
\hline & $\mathbf{5}_{6 / 85}$ vaccinated, IBV & 30.6 & $2,371.4$ & 487.7 & $17,690.4$ & $5,986.1$ & 470.5 & 1,608 & $5,915.4$ & 1.4 \\
\hline & challenged & \pm 7.3 & $\pm 2,147.3$ & \pm 319.4 & $\pm 6,793.8$ & $\pm 1,698.2$ & \pm 364.0 & \pm 43.2 & $\pm 8,136.8$ & \pm 2 \\
\hline & $\mathbf{6}_{6 / 85}$ vaccinated, & $5,779.4$ & $7,059.1$ & $2,453.9$ & $4,555.7$ & 726.4 & 93.1 & 57.5 & 537.0 & 54.4 \\
\hline & MG+IBV challenged & $\pm 3,017.0$ & $\pm 8,126.6$ & $\pm 3,145.7$ & $\pm 1,864.0$ & \pm 165.8 & \pm 20 & \pm 30.6 & \pm 186.5 & \pm 47 \\
\hline
\end{tabular}

$<100$ genome copies

100-1,000 genome copies

1,000-10,000 genome copies

10,000-100,000 genome copies

$>100,000$ genome copies

MG: Mycoplasma gallisepticum

IBV: infectious bronchitis virus 